\title{
Extraction of polyphenols from different herbs for the development of functional date bars
}

\author{
Muhammad Naeem SAFDAR ${ }^{1 \star}$ (D), Umer Yousaf BAIG ${ }^{2}$, Muhammad Muneeb RIAZ ${ }^{2}$, Amer MUMTAZ ${ }^{1}$, \\ Saqib JABBAR ${ }^{1}$, Dua-E-ZEHRA², Naqib-UR-REHMAN², Zain AHMAD², Hira MALIK ${ }^{2}$, Shahid YOUSAF ${ }^{1}$
}

\begin{abstract}
An investigation was conducted to extract polyphenols from moringa leaf, tamarind seed, mint and lemongrass for the development of functional date bars. Solvent methanol, ethanol and acetone at 50\% and 75\% concentration was employed for polyphenols extraction through ultrasound assisted extraction technique.Higher polyphenols and flavonoids were extracted from moringa leaf with comparatively more antioxidant activity than other herbs studied. Date bars fortified with different levels of moringa leaf and tamarind seedpolyphenolic extracts had optimum quality attributes and antioxidant activity as well assensory acceptable. Overall, $2 \%$ moringa leaf extract fortified date bars scored highest and were appreciated most by sensory panelists whereas 3\% tamarind seed extract fortified date bars scored lowest and were disliked most. It was concluded that moringa leaf and tamarind seed extract being a potential source of polyphenols could be developed as ingredient for the preparation of functional foods.
\end{abstract}

Keywords: herbs; polyphenols; antioxidant activity; functional foods; date bars.

Practical Application: Polyphenols are the plants natural antioxidants/phytochemicals having animportant role in human health by prevention of certain oxidative stress related degenerative diseases. Moringa leaf, tamarind seed, mint and lemongrass are herbsof high medicinal value pertaining to their high polyphenol content. Moringa leaf and tamarind seed polyphenolic extract fortified date bars and other functional foods may be prepared and utilized as a preventive and alternate therapeutic measure against certain oxidative stress related diseases.

\section{Introduction}

Oxidative stress is a phenomenon caused by an imbalance between production and accumulation of oxygen reactive species (ROS) in cells /tissues and the ability of a biological system to detoxify these reactive products. It can negatively affect several cellular structures, such as membranes, lipids, proteins, lipoproteins, and deoxyribonucleic acid (DNA). Oxidative stress can also cause modifications in DNA structure i.e. DNA-protein cross-linksbase and sugar lesions, strand breaks and base-free sites (Pizzino et al., 2017). Polyphenols are secondary metabolites produced by higher plants, which play multiple essential roles in plant physiology and have potential healthy properties on human organism, mainly as antioxidants, anti-allergic, antiinflammatory, anticancer, antihypertensive, and antimicrobial agents. There is substantial epidemiological evidence that a diet high in polyphenol rich fruits, vegetables, cocoa, dark chocolate and tea protects against developing cardiovascular disease, type 2 diabetes and certain cancers (Daglia, 2012; Williamson, 2017).

Herbs are known to serve as powerful antioxidants.Mint(Mentha Longifolia L.)is a genus of plants in the family Lamiaceae thatcontainspolyphenols especially rosmarinic acid which is an antioxidant as well as anti-inflammatory agent (Tahira et al., 2011). Medicinal effects of mint are closely associated with the high content of phenolic compoundsthat exhibit antimicrobial and antiviral activities (Mimica-Dukic \& Bozin, 2008). Lemongrass (Cymbopogoncitratus)is a herb that contains several antioxidants, which can help scavenge free radicals in the body that may cause certain oxidative stress related diseases. Tamarind (Tamarindus Indica) is a natural laxative, helps control blood pressureand heart rate by maintaining normal fluid balance in the body whereas Moringa oleifera is a perennial deciduous tropical plant, rich in many bioactive compounds and possesses many pharmacological properties such as antioxidant,anti-inflammatory,anti-cancer, anti-diabeticandantimicrobial (Gopalakrishnan et al., 2016; Ma et al., 2020). During a study, Farooq et al. (2012) observed that aqueous extracts of moringa exhibited inhibitory against many pathogenic bacteria including Staphylococcus aureus, Bacillus subtilis, Escherichia coli, and Pseudomonas aeruginosain dose dependent manner.

Ultrasound-assisted extraction (UAE) of polyphenols involves mixingthe sample with organic solvent in a flask or beaker and insertion it in an ultrasonic bath with pre-set time and temperature.Sound waves are produced during the processwhich ruptures sample cell walls, thus lead to extraction ofphenolic compounds. Generally, ultrasound-assisted extraction 
time is less than $1 \mathrm{~h}$, but the extraction yield is $6-35 \%$ more than traditional extraction techniques with longer extraction time of 12 or more hours (Aadil et al., 2015; Wong Paz et al., 2015). Generally, methanol and ethanol are employed for the extraction of polyphenols from plants. It was observed that aqueous methanol was comparatively efficient solvent than ethanol and acetone for polyphenols extraction from different medicinal plant extracts (Sultana et al., 2009).

Antioxident activity determination of polyphenols in vitro is generally is carried out using various assays such as ferric reducing antioxidents power (FRAP) 2,2-diphenyl-1-picrylhydrazyl (DPPH) superoxide redical scavenging assay and oxygen redical absorbance capacity (ORAC). However, DPPH radical scavenging assay is the most popular and widely used technique to evaluate antioxident capacity (Pérez-Jiménez et al., 2009).

Due to current busy lifestyle, convenient foods like cereals/legumes bars are becoming popular among masses. Functional foods are natural or processed foods that provide besides basic nutrition additional physiological benefits in the treatment/management and prevention of various chronic disorders (Orrego et al., 2014). Owing to be a rich source of antioxidants especially polyphenols, different herbs such as moringa, mint, tamarind and lemongrass were examined to extract polyphenols from these herbs, to assess their antioxidant activity and to develop functional date bars containing extracted polyphenols.

\section{Materials and methods}

\subsection{Plant material}

Different herbs such as Mint, Moringa, Tamarind and lemongrass were procured from local market, Islamabad, taken to Food Science Research Institute Lab(FSRI), National Agricultural Research Centre, Islamabad. Fresh weight of was taken on top load balance and were dried in hot air oven at $50{ }^{\circ} \mathrm{C}$ for 48 hours until moisture content of leaves reduced to $10 \%$ or below. Dried materials were firstly crushed in pestle morter and then milled in a Cyclotech mill with sieve size $0.5 \mathrm{~mm}$. The milled powder with particle diameter $0.5 \mathrm{~mm}$ was packed in air tight zip bags and stored at refrigeration temperature $4{ }^{\circ} \mathrm{C}$ for further studies. Moreover, for analytical analysis Lab graded chemicals were used.

\subsection{Extraction of polyphenols}

Ultrasound assisted extraction technique was employed for extraction of polyphenols from mint, moringa, tamarind and lemongrass powders according to procedure depicted by Bimakr et al. (2013) with minor variations. Powdered herb samples were extracted with solvents methanol, ethanol and acetone at two solvent concentrations (50\%, 75\%\%), sample to sovent ratio $1: 20$, at extraction temperature and time $45^{\circ} \mathrm{C}$ and 60 minutes respectively in a sonicator set at $35 \mathrm{kHz}$ frequency with $100 \%$ amplitude level. Extracts were filtered, centrifuged, solvent evaporated by vacuum evaporator, collected in amber glass bottles and refrigeratedstored.

\subsection{Yield (\%) of herb extracts}

The percent yield of herb extracts through maceration and UAE was assessed by dividing the weight of the extract with the sample weight and multiplying by 100 .

\subsection{Total polyphenols determination}

The total polyphenol content of extracts was measured by the Folin-Ciocalteau method as described by Singleton et al. (1999). Briefly, $0.5 \mathrm{~mL}$ extract solution was mixed with $2.5 \mathrm{~mL}$ of $10 \%$ Folin-Ciocalteu's reagent dissolved in distilled water and $2.5 \mathrm{~mL}$ $7.5 \%$ sodium carbonate. Then the samples were incubated at $25^{\circ} \mathrm{C}$ for $30 \mathrm{~min}$. The absorbance was measured at $765 \mathrm{~nm}$ with UV-vis Spectrophotometer (Agilent 8453, Santa Clara, CA). A similar procedure was carried out in gallic acid standard solution and the calibration curve was prepared from various concentrations of gallic acid ( 0 to $400 \mu \mathrm{g} / \mathrm{mL}$ ). The regression equation calculated as $\mathrm{Y}=0.0092 \mathrm{X}+0.1459$ with $\mathrm{R}^{2}=0.9948$. Total polyphenol content was expressed as mg gallicacid equivalent (GAE)/gof extract.

\subsection{Total flavonoids determination}

Total flavonoid contents (TFC) were measured according to procedure described by spectrophotometric method (Dewanto et al., 2002). Briefly, extracts of each plant material $(10 \mathrm{mg} / \mathrm{mL})$ were diluted with water $(4 \mathrm{~mL})$ in a $10 \mathrm{~mL}$ volumetric flask. Initially, $5 \% \mathrm{NaNO}_{2}$ solution $(0.3 \mathrm{~mL})$ was added to each volumetric flask; at $5 \mathrm{~min}, 10 \% \mathrm{AlCl}_{3}(0.3 \mathrm{~mL})$ was added; and at $6 \mathrm{~min}, 1.0 \mathrm{M} \mathrm{NaOH}(2 \mathrm{~mL})$ was added. Water $(2.4 \mathrm{~mL})$ was then added to the reaction flask and mixed well. Absorbance of the reaction mixture was read at $510 \mathrm{~nm}$. TFC were determined as mgquercetin equivalent/g of extract).

\subsection{Antioxidant activityevaluation}

The antioxidant activity of different herb extracts was measured using the DPPH (1,1-diphenyl-2-picryl-hydra-zyl) assay according to the method described by Brand-Williams et al. (1995) with slight modifications. Briefly, $24 \mathrm{mg}$ DPPH was dissolved in $100 \mathrm{~mL}$ methanol to prepare a stock solution. The working standards were prepared by diluting DPPH stock solution with methanol to obtain about $0.98( \pm 0.02)$ absorbance at $517 \mathrm{~nm}$. Then, $3 \mathrm{~mL}$ of the solutionwas mixed with $100 \mathrm{~mL}$ of samples at different concentrations (25 and $400 \mathrm{mg} / \mathrm{mL}$ ), shaken well, incubated in the dark at room temperature for 15 minutes and absorbance was measured at $517 \mathrm{~nm}$. A parallel control (without extract) and standard ascorbic acid were also analyzed in a similar manner. The scavenging activity was calculated based on the DPPH radical percentage scavenged (Formula 1).

$\%$ Inhibition of DPPH radical $=\frac{A_{c}-A_{s}}{\mathrm{~A}_{c}} \times 100$

where $\mathrm{A}_{\mathrm{c}}$ is the absorbance of control and $\mathrm{A}_{\mathrm{s}}$ is the absorbance of solvent.

\subsection{Development of functional date bars}

Date Bars (25 g each) were prepared by mixing date paste (55\%), roasted gram(16\%) |and corn flour(16\%), peanuts(6\%), 
almonds (6\%), common salt (0.9\%) and potassium sorbate $(0.1 \%)$. Moringa leaf and Tamarind seed polyphenolic extracts of $2 \%$ and 3\% concentration levels were added in different bars along with control bars without herb extracts. Then the mixture was transferred to cutting and sheeting table where sheeting was carried out with sheeting roller and cut into date bars of $7 \mathrm{~cm}$ length, $2.5 \mathrm{~cm}$ width and $1 \mathrm{~cm}$ height. Date bars were placed in hot air oven at $45{ }^{\circ} \mathrm{C}$ for $25 \mathrm{~min}$. Each bar of approximately $25 \mathrm{~g}$ was packed in butter paper along with aluminium foil and stored in refrigerator.

\subsection{Physiochemical analysis of date bars}

The date paste and the functional date bars were subjected to physiochemical analysis including TSS (total soluble solids), titratable acidity and total sugars. TSS was determined by Atago Hand Refractometer. Few drops of the sample were placed on the refrectometer prism. Then TSS of sample was noted from the refrectometerbrix scale with dark band, multiplied by the the dilution factor which was corrected at $20^{\circ} \mathrm{C}$ from table 900.03 (Association of Official Agricultural Chemists, 2016).

Percent acidity of date paste and functional date bars was determined according to standard mothod of Association of Official Agricultural Chemists (2016). Five-gram sample was taken and titrated against $0.1 \mathrm{~N} \mathrm{NaOH}$ using phenolphthalein as indicator till pink endpoint. Percent acidity was calculated by following Formula 2:

Percent acidity $=\frac{1 \times 0.1 \mathrm{~N} \text { of } \mathrm{NaOH} x \text { equivalent weight } x \text { titre value }}{10 x \text { weight of sample }}$

Sugars were determined by the Lane Eynon titrimetric method as reported in Association of Official Agricultural Chemists (2016). Titration was carried out until the blue color changed into brick red color (Formula 3).

Total sugars $=\frac{(0.032)(\text { solution } A)(\text { solution } B)(100)}{(10 \text { g sample })(50)(\text { titrated value })}$

\subsection{Total polyphenols and antioxidant activity determination of date bars}

Total polyphenols content and antioxidant activity determination of different date bars were estimated by the same procedures described earlier for herbs polyphenolic extracts.

\subsection{Sensory evaluation}

Sensory evaluation was conducted in Food Science Research Institute at the National Agricultural Research Center, Islamabad. Sensory evaluation performa (9-point hedonic scale) was used to determine the preferences in color, taste, flavor, and texture according to procedure by Stone \& Sidal (1998). Seven sensory judges were advised to examine each sample carefully. Sensory evaluation was performed in a testing room with normal lights.

\subsection{Statistical analysis}

Data were statistically analyzed by applying analysis of variance (ANOVA) technique to determine significance level. The least square design test was used to calculate least significant difference between means. Minitab software was used for conducting statistical analysis of data.

\section{Results and discussion}

\subsection{Extraction yield}

The percent yield of herb extracts through ultrasoundassisted extraction at different solvent concentration levels shows that highest and lowest extraction yield was obtained from lemongrass extract (26.69\%) with solvent ethanol at 50\% concentration level and tamarind seed extract (10.87\%) with 50\% acetone respectively (Table 1). Statistically, solvent concentration levels were significantly different from each other for solvent acetone, while there were non-significant difference between yield at concentration levels $50 \%$ and $75 \%$ for solvent methanol and ethanol. However, the solvent concentration level $50 \%$ was more effective than $75 \%$ solvent concentration of all solvents employed. Variations in extraction yield among different solvents may be due to their polarities difference. Efficiency of extracting solvent to dissolve endogenous compounds may be one of the important contributing factor (Sultana et al., 2007). Similarly, Wang et al. (2008) reported that the yield of phenolic compounds from plants was related to certain extraction parameters like solvent concentration, extraction time and temperature.

\subsection{Total polyphenols, flavonoids and antioxidant activity of herb extracts}

Among the different herb extracts, highest polyphenols were extracted in moringa leaf methanolic extract $(30.85 \pm 0.89 \mathrm{mg}$ $\mathrm{GAE} / \mathrm{g}$ of extract) at $50 \%$ concentration level whereas lemongrass $75 \%$ methanolic extract exhibited lowest phenolic compounds (11.02 $\pm 0.64 \mathrm{mg} \mathrm{GAE} / \mathrm{g}$ of extract) (Table 2). LSD-test indicates that methanol concentration levels had a significant effect on extraction of polyphenols and were significantly different from each other for othersolvents at all concentration levels.Total polyphenols determined from the moringa leaves investigated in the present studyweremore thanthatreportedby Sultana et al. (2009) during her work on different medicinal plants.However, tamarind seed extract polyphenols analyzed during study were less than those reported by Razali et al. (2015) in tamarind seed methanolic extract.

Total flavonoid contents of different herbs extracted with three different solvents (Table 3 ) reveals that moringa leaf methanolic extract ( $16.27 \pm 0.61 \mathrm{mg} \mathrm{QE} / \mathrm{g}$ of extract) at $50 \%$ concentration level exhibited highest flavonoids content while lemongrass $75 \%$ methanolic extract exhibited lowest phenolic compounds (6.84 $\pm 0.48 \mathrm{mg} \mathrm{QE} / \mathrm{g}$ of extract). Overall, methanol was the most efficient solvent for extraction of flavoids for different herbs studied. LSD-test indicates that methanol concentration levels had a significant effect on extraction of flavoids and were significantly different from each other for other solvents at all concentration levels. Total flavoids determined from the moringa 
Original Article

Herbs Extracted Polyphenols Fortified Date Bars

Table 1. Effect of extracting solvent on extract yield (\%) of different herbsextract.

\begin{tabular}{|c|c|c|c|c|c|c|}
\hline \multirow{2}{*}{ Herbs } & \multicolumn{2}{|c|}{ Methanol } & \multicolumn{2}{|c|}{ Ethanol } & \multicolumn{2}{|c|}{ Acetone } \\
\hline & $50 \%$ & $75 \%$ & $50 \%$ & $75 \%$ & $50 \%$ & $75 \%$ \\
\hline \multirow[t]{2}{*}{ Moringa leaf } & $25.87^{\mathrm{ab}}$ & $21.79^{\mathrm{cd}}$ & $13.44^{\mathrm{i}}$ & $16.28^{g}$ & $14.06^{\mathrm{h}}$ & $12.84^{j}$ \\
\hline & \pm 0.98 & \pm 0.67 & \pm 0.39 & \pm 0.54 & \pm 0.61 & \pm 0.53 \\
\hline \multirow[t]{2}{*}{ Mint } & $18.43^{\mathrm{e}}$ & $17.60^{\mathrm{f}}$ & $12.72^{j}$ & $13.99^{\mathrm{hi}}$ & $16.48^{\mathrm{g}}$ & $14.85^{\mathrm{h}}$ \\
\hline & \pm 0.84 & \pm 0.56 & \pm 0.48 & \pm 0.36 & \pm 0.57 & \pm 0.77 \\
\hline \multirow[t]{2}{*}{ Tamarind seed } & $17.74^{\mathrm{f}}$ & $21.67^{c}$ & $15.97^{\text {gh }}$ & $12.97^{\mathrm{i}}$ & $10.87^{\mathrm{k}}$ & $12.13^{j}$ \\
\hline & \pm 1.80 & \pm 0.88 & \pm 0.77 & \pm 0.31 & \pm 0.67 & \pm 0.76 \\
\hline \multirow[t]{2}{*}{ Lemongrass } & $21.79^{\mathrm{cd}}$ & $20.44^{\mathrm{d}}$ & $26.69^{a}$ & $23.15^{\mathrm{b}}$ & $21.39^{c}$ & $18.21^{\mathrm{ef}}$ \\
\hline & \pm 0.73 & \pm 0.63 & \pm 0.52 & \pm 0.48 & \pm 0.42 & \pm 0.61 \\
\hline \multirow[t]{2}{*}{ Mean } & $20.96^{A}$ & $20.37^{\mathrm{A}}$ & $17.20^{\mathrm{B}}$ & $16.60^{\mathrm{B}}$ & $15.70^{\mathrm{C}}$ & $14.51^{\mathrm{D}}$ \\
\hline & \pm 1.27 & \pm 0.71 & \pm 0.56 & \pm 0.39 & \pm 0.43 & \pm 0.57 \\
\hline
\end{tabular}

Means followed by same letters do not differ significantly $(\mathrm{p}<0.05)$. Different superscript letters within same row denote a significant difference $(\mathrm{p}<0.05)$.

Table 2. Effect of extracting solvent on total polyphenol content (mg GAE/g of extract) of different herbs extract.

\begin{tabular}{|c|c|c|c|c|c|c|}
\hline \multirow{2}{*}{ Herbs } & \multicolumn{2}{|c|}{ Methanol } & \multicolumn{2}{|c|}{ Ethanol } & \multicolumn{2}{|c|}{ Acetone } \\
\hline & $50 \%$ & $75 \%$ & $50 \%$ & $75 \%$ & $50 \%$ & $75 \%$ \\
\hline \multirow[t]{2}{*}{ Moringa leaf } & $30.85^{\mathrm{a}}$ & $28.84^{\mathrm{b}}$ & $26.16^{c}$ & $24.21^{\mathrm{de}}$ & $21.92^{\mathrm{f}}$ & $22.83^{\text {ef }}$ \\
\hline & \pm 0.89 & \pm 0.51 & \pm 0.64 & \pm 0.46 & \pm 0.80 & \pm 0.42 \\
\hline \multirow[t]{2}{*}{ Mint } & $25.12^{\mathrm{d}}$ & $23.57^{e}$ & $19.85^{\mathrm{g}}$ & $17.98^{\mathrm{hi}}$ & $22.29^{\mathrm{ef}}$ & $18.19^{\mathrm{h}}$ \\
\hline & \pm 0.58 & \pm 0.43 & \pm 0.32 & \pm 0.53 & \pm 0.71 & \pm 0.91 \\
\hline \multirow[t]{2}{*}{ Tamarind seed } & $24.71^{\text {de }}$ & $27.51^{\mathrm{bc}}$ & $22.73^{\mathrm{ef}}$ & $21.66^{\mathrm{f}}$ & $21.75^{\mathrm{f}}$ & $20.04^{\mathrm{fg}}$ \\
\hline & \pm 0.81 & \pm 0.57 & \pm 0.53 & \pm 0.41 & \pm 0.76 & \pm 0.45 \\
\hline \multirow[t]{2}{*}{ Lemongrass } & $13.97^{j}$ & $11.02^{\mathrm{k}}$ & $18.64^{\mathrm{h}}$ & $16.27^{\mathrm{i}}$ & $20.38^{\mathrm{fg}}$ & $19.90^{\mathrm{g}}$ \\
\hline & \pm 1.02 & \pm 0.64 & \pm 0.28 & \pm 0.39 & \pm 0.57 & \pm 0.39 \\
\hline \multirow[t]{2}{*}{ Mean } & $23.66^{A}$ & $22.73^{\mathrm{A}}$ & $21.84^{\mathrm{B}}$ & $20.03^{C}$ & $21.58^{\text {B }}$ & $20.24^{\mathrm{C}}$ \\
\hline & \pm 0.77 & \pm 0.46 & \pm 0.37 & \pm 0.42 & \pm 0.62 & \pm 0.54 \\
\hline
\end{tabular}

Means followed by same letters do not differ significantly $(\mathrm{p}<0.05)$. Different superscript letters within same row denote a significant difference $(\mathrm{p}<0.05)$.

Table 3. Effect of extracting solvent on total flavonoid content (mg QE/g of extract) of different herbs extract.

\begin{tabular}{|c|c|c|c|c|c|c|}
\hline \multirow{2}{*}{ Herbs } & \multicolumn{2}{|c|}{ Methanol } & \multicolumn{2}{|c|}{ Ethanol } & \multicolumn{2}{|c|}{ Acetone } \\
\hline & $50 \%$ & $75 \%$ & $50 \%$ & $75 \%$ & $50 \%$ & $75 \%$ \\
\hline \multirow[t]{2}{*}{ Moringa leaf } & $16.27^{\mathrm{a}}$ & $13.78^{b c}$ & $14.05^{c}$ & $12.62^{\mathrm{d}}$ & $10.74^{\mathrm{de}}$ & $11.83^{\mathrm{d}}$ \\
\hline & \pm 0.61 & \pm 0.66 & \pm 0.52 & \pm 0.39 & \pm 0.90 & \pm 0.43 \\
\hline \multirow[t]{2}{*}{ Mint } & $14.09^{c}$ & $12.37^{\mathrm{d}}$ & $9.98^{\mathrm{e}}$ & $9.01^{\mathrm{ef}}$ & $12.63^{c}$ & $10.12^{\mathrm{d}}$ \\
\hline & \pm 0.37 & \pm 0.73 & \pm 0.23 & \pm 0.32 & \pm 0.49 & \pm 0.37 \\
\hline \multirow[t]{2}{*}{ Tamarind seed } & $15.38^{\mathrm{b}}$ & $16.23^{\mathrm{a}}$ & $12.47^{\mathrm{c}}$ & $11.29^{\mathrm{d}}$ & $12.10^{c}$ & $13.54^{\mathrm{bc}}$ \\
\hline & \pm 0.41 & \pm 0.66 & \pm 0.57 & \pm 0.76 & \pm 0.83 & \pm 0.35 \\
\hline \multirow[t]{2}{*}{ Lemongrass } & $8.56^{\mathrm{f}}$ & $6.84^{\mathrm{g}}$ & $10.92^{\mathrm{de}}$ & $9.13^{\text {ef }}$ & $11.45^{\mathrm{d}}$ & $13.11^{\mathrm{bc}}$ \\
\hline & \pm 0.65 & \pm 0.48 & \pm 0.57 & \pm 0.75 & \pm 0.54 & \pm 0.87 \\
\hline \multirow[t]{2}{*}{ Mean } & $13.57^{\mathrm{A}}$ & $12.30^{\mathrm{B}}$ & $11.85^{\mathrm{C}}$ & $10.51^{\mathrm{D}}$ & $11.73^{\mathrm{C}}$ & $12.15^{\mathrm{B}}$ \\
\hline & \pm 0.61 & \pm 0.52 & \pm 0.46 & \pm 0.59 & \pm 0.49 & \pm 0.33 \\
\hline
\end{tabular}

Means followed by same letters do not differ significantly $(p<0.05)$. Different superscript letters within same row denote a significant difference $(p<0.05)$.

leaves investigated in the present study were higher than that reported by Sultana et al. (2009) during her study on different medicinal plants.

DPPH radical scavenging activity of different herbs methanolic extracts at different concentration levels (Table 4) reveals higher antioxidant activity of all sample extracts. However, maximum radical scavenging activity $(74.88 \pm 0.96 \%)$ was exhibited by moringa leaf methanolic extract at $50 \%$ concentration level followed by moringa leaf $75 \%$ methanolic extract $(72.10 \pm$ $0.67 \%)$ whereas lemongrass $75 \%$ methanolic extracts had the minimum scavenging activity $(40.64 \pm 0.76 \%)$. It has been well established that free radical scavenging activity of plant extracts is positively correlated to phenolic compounds (Sultana et al., 2009; Wong et al., 2014; Safdar et al., 2017). 
Table 4. Effect of extracting solvent on DPPH radical scavenging activity (\%) of different herbs extract.

\begin{tabular}{|c|c|c|c|c|c|c|}
\hline \multirow{2}{*}{ Herbs } & \multicolumn{2}{|c|}{ Methanol } & \multicolumn{2}{|c|}{ Ethanol } & \multicolumn{2}{|c|}{ Acetone } \\
\hline & $50 \%$ & $75 \%$ & $50 \%$ & $75 \%$ & $50 \%$ & $75 \%$ \\
\hline \multirow[t]{2}{*}{ Moringa leaf } & $74.88^{\mathrm{a}}$ & $72.10^{\mathrm{b}}$ & $67.27^{c}$ & $57.61^{\mathrm{fg}}$ & $53.08^{\mathrm{gh}}$ & $55.29^{\mathrm{g}}$ \\
\hline & \pm 0.53 & \pm 0.67 & \pm 2.55 & \pm 3.59 & \pm 0.87 & \pm 0.39 \\
\hline \multirow[t]{2}{*}{ Mint } & $60.56^{\mathrm{f}}$ & $53.72^{\mathrm{g}}$ & $51.01^{\mathrm{h}}$ & $48.14^{\mathrm{i}}$ & $54.47^{\mathrm{g}}$ & $50.98^{\mathrm{h}}$ \\
\hline & \pm 2.71 & \pm 3.50 & \pm 0.91 & \pm 0.77 & \pm 1.31 & \pm 0.88 \\
\hline \multirow[t]{2}{*}{ Tamarind seed } & $62.35^{\mathrm{e}}$ & $65.41^{\mathrm{d}}$ & $55.37^{\mathrm{g}}$ & $52.28^{\mathrm{gh}}$ & $51.12^{\mathrm{h}}$ & $54.46^{\mathrm{g}}$ \\
\hline & \pm 0.89 & \pm 0.98 & \pm 1.45 & \pm 0.54 & \pm 0.95 & \pm 0.84 \\
\hline \multirow[t]{2}{*}{ Lemongrass } & $44.23^{j}$ & $40.64^{\mathrm{k}}$ & $50.16^{\mathrm{h}}$ & $47.05^{\mathrm{i}}$ & $52.48^{\mathrm{h}}$ & $60.17^{f}$ \\
\hline & \pm 1.32 & \pm 0.76 & \pm 0.78 & \pm 0.51 & \pm 2.55 & \pm 1.61 \\
\hline \multirow[t]{2}{*}{ Mean } & $60.50^{A}$ & $57.96^{\mathrm{B}}$ & $55.95^{\mathrm{C}}$ & $51.27^{\mathrm{D}}$ & $52.78^{\mathrm{D}}$ & $55.22^{\mathrm{C}}$ \\
\hline & \pm 0.41 & \pm 0.82 & \pm 1.42 & \pm 0.95 & \pm 0.79 & \pm 1.66 \\
\hline
\end{tabular}

Means followed by same letters do not differ significantly $(\mathrm{p}<0.05)$. Different superscript letters within same row denote a significant difference $(\mathrm{p}<0.05)$.
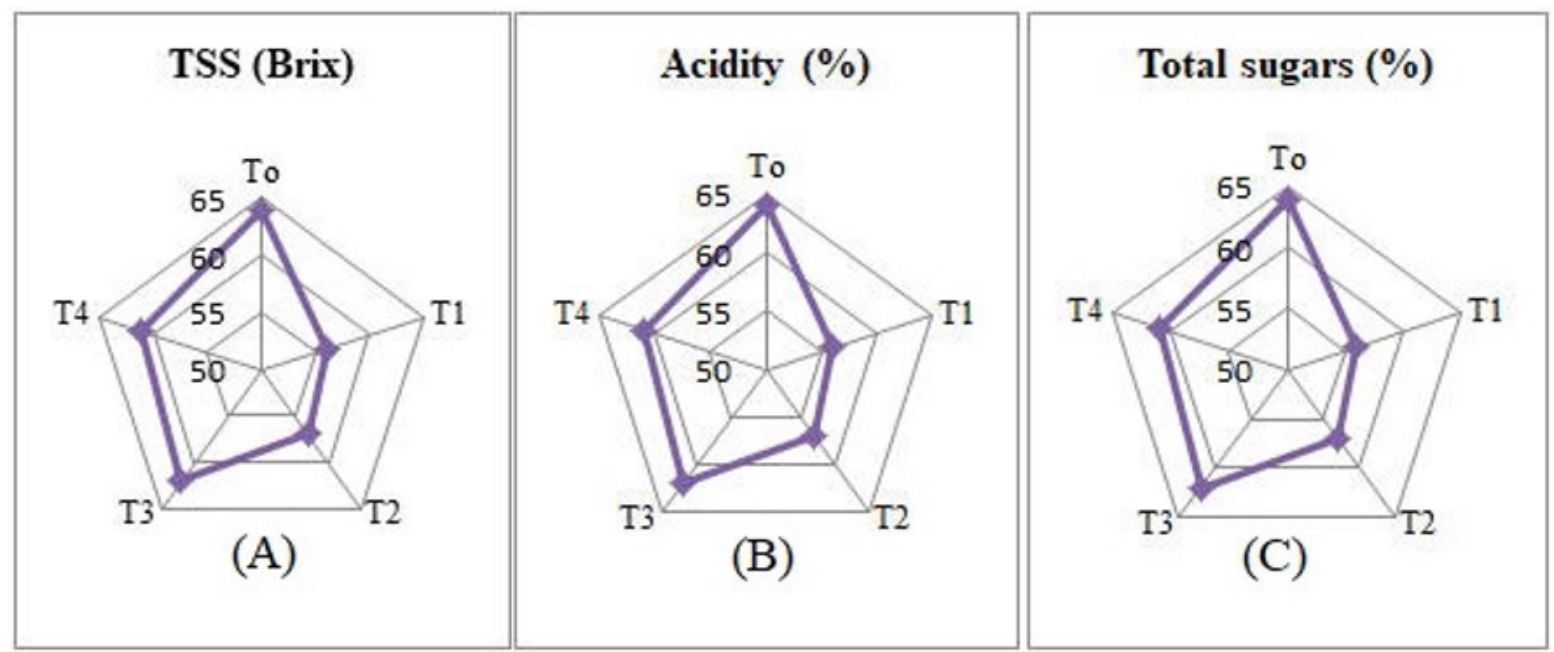

Figure 1. Physicochemical Analysis of Date bars: $\mathrm{T}_{0}$ : Control date bars; $\mathrm{T}_{1}: 2 \%$ Moringa leaf extract fortified date bars; $\mathrm{T}_{2}: 3 \% \mathrm{Moringa}$ leaf extract fortified date bars; $\mathrm{T}_{3}: 2 \%$ Tamarind seed extract fortified date bars; $\mathrm{T}_{4}: 3 \%$ Tamarind seed extract fortified date bars.

\subsection{Development of functional date bars}

Moringa leaf and tamarind seed ethanolic extracts 50\% concentration were utilized for the development of functional date bars since solvent ethanol is recommended by food and drug administration for its application in food system. The Total soluble solids (TSS) consists of predominantly the carbohydrates such as sucrose, fructose and glucose but proteins, fats, organic acids and minerals content of the food sample are also its components.TSS of freshly prepared date bars (Figure 1A) ranged from $56.10 \pm$ $0.10^{\circ} \mathrm{Brix}\left(\mathrm{T}_{1}\right)$ to $64.20 \pm 0.15^{\circ} \mathrm{Brix}\left(\mathrm{T}_{0}\right)$.LSD-test revealed that TSS of control date bars $\left(\mathrm{T}_{0}\right)$ weresignificantly different from other treatment bars.

Date bars treatment $\mathrm{T}_{3}$ and $\mathrm{T}_{4}$ were non-significant to each other but were significantly different from other treatments. Results were in agreement with the findings of Ranjha et al. (2020) who reported TSS $62.5^{\circ} \mathrm{Brix}$ of control date bars.As regards percent acidity of date bars (Figure 1B) highest percent acidity was recorded in date bars $\mathrm{T}_{3}(0.61 \pm 0.02 \%)$ while control fruit bars $\mathrm{T}_{0}$ exhibited the minimum acidity $(0.49 \pm 0.03 \%)$. The percent acidity of date bars increased with the enhancement of fortification level of polyphenolic extract which might be due to the fact that polyphenols are bitter in nature. Total sugars of date bars fortified with different levels of moringa leaf and tamarind seed extracts varied significantly among treatments. Maximum total sugars (\%) wereanalyzed in date bars $\mathrm{T}_{0}(53.10 \pm 0.16 \%)$ while treatment $\mathrm{T}$, had the minimum total sugars $(45.40 \pm 0.25 \%)$ (Figure 1C). Similar higher total sugars of control date bars were earlier reported in apple and pomegranate peel polyphenolic extract fortified date bars (Ranjha et al., 2020).

\subsection{Total polyphenol and antioxidant activity of fruit bars}

Total polyphenol content of date bars fortified with moringa leaf and tamarind seed polyphenolic extractsat $2 \%$ and 3\% levels varied significantly among treatments (Figure 2A). Maximum total polyphenols was analyzed in fruit bars $\mathrm{T}_{2}(251.99 \pm 10.24 \mathrm{mg}$ $\mathrm{GAE} /$ date bar) whereas control date bars $\mathrm{T}_{0}^{2}$ had the minimum polyphenol content $(24.13 \pm 3.61 \mathrm{mg} \mathrm{GAE} /$ date bar).Total polyphenolic content of date bars enhanced as the fortification level of herb extracts increased. It was observed that date bars fortified with moringa leafpolyphenolic extracts had comparatively 


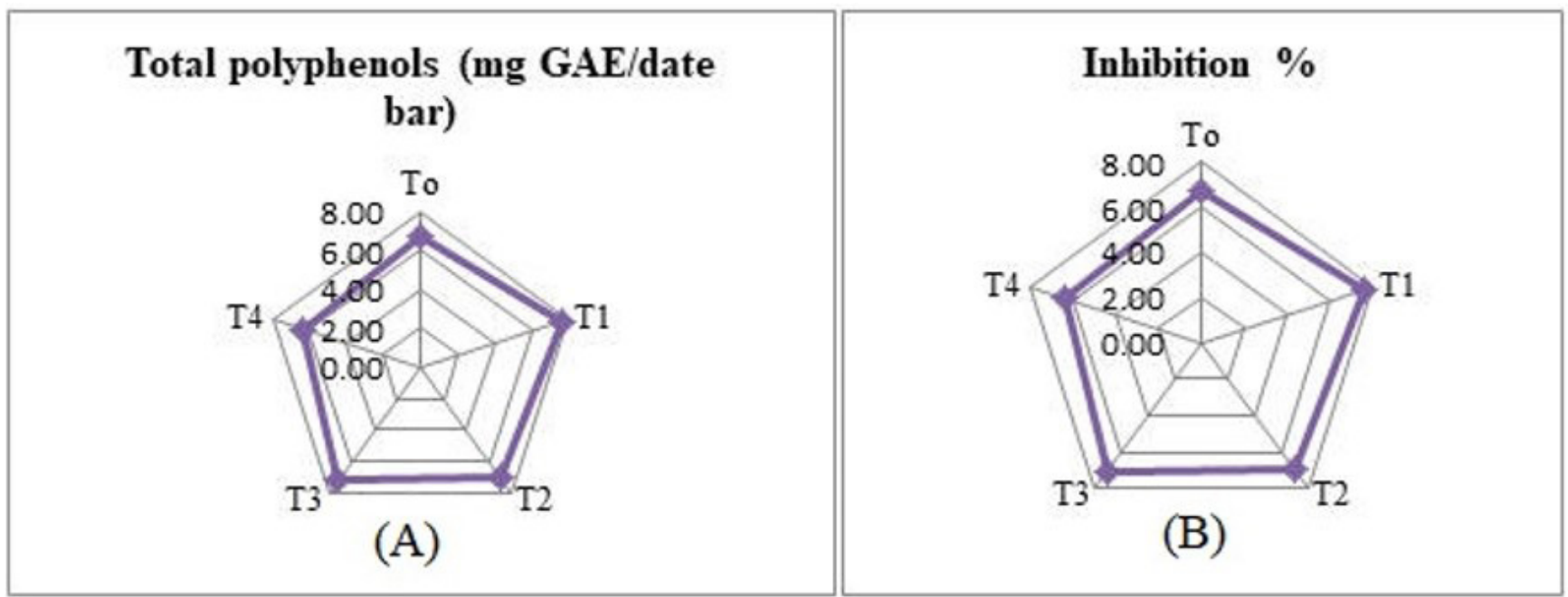

Figure 2. Total Polyphenol Content and DPPH Scavenging Activity of Date bars. $\mathrm{T}_{0}$ : Control date bars; $\mathrm{T}_{1}: 2 \%$ Moringa leaf extract fortified date bars; $\mathrm{T}_{2}: 3 \%$ Moringa leaf extract fortified date bars; $\mathrm{T}_{3}: 2 \%$ Tamarind seed extract fortified date bars; $\mathrm{T}_{4}: 3 \%$ Tamarind seed extract fortified date bars.

more polyphenol content than tamarind seed polyphenolic extractsdate bars. Results were in comparison with the earlier investigations reported by Ranjha et al. (2020) in pomegranate and apple peel extract fortified date bars with the total polyphenols ranged from 27.23 to $262.58 \mathrm{mg} \mathrm{GAE} / \mathrm{g}$ of extract.

DPPH radical scavenging activity of date bars fortified with different levels of moringa leaf and tamarind seed polyphenolic extractsvaried significantly among treatments (Figure 2B). Highest scavenging activity or percent inhibition was recorded in date barstratment $\mathrm{T}_{3}(61.37 \pm 1.13 \%)$ whereas control date bars $\mathrm{T}_{0}$ had the lowest radical scavenging activity or percent inhibition $(19.64 \pm 1.03 \%)$. LSD-test indicated that control datebars $\left(\mathrm{T}_{0}\right)$ scavenging activity were significantly different from other treatment bars. The antioxidant activity of date bars fortified with elevated concentration of polyphenolic extracts (3\%) was comparatively more than control date bars and other low polyphenolic extract fortified date bars which revealed that the antioxidant activity of date bars was attributed to the total polyphenolic content of date bars. Jethwani et al. (2020) reported a significant increase in antioxidant activity of mangochia seed bars (antioxidant rich bars) as compared to control bars.

\subsection{Sensory characteristics of fruit bars}

Colour is one of the important quality parameter of food and food products that plays a key role in the food preference and acceptability. Colour/appearance score of date bars showed that treatment $\mathrm{T}_{1}$ got maximum colour/appearance score $(7.81 \pm$ 0.14 ) whereas treatment $T_{4}$ had the minimum colour/appearance score $(6.14 \pm 0.19)$ (Figure 3A). LSD-test revealed that colour score of treatment $\mathrm{T}_{1}$ date bars was significantly different from other treatment bars.

Sugars and acid ratio primarily creates a taste sense which is recognized by the specialized taste buds present on the tongue. Taste score of date bars fortified with different levels of moringa leaf and tamarind seed polyphenolic extracts varied significantly among treatments. Date bars treatment $\mathrm{T}_{1}$ awarded highest taste score $(7.57 \pm 0.17)$ whereas treatment $\mathrm{T}_{4}$ got the lowest taste score $(6.57 \pm 0.08)$ by the sensory panelists (Figure $3 \mathrm{~B}$ ). Variation in taste score of date bars among different treatments might be attributed to difference in their acidity, $\mathrm{pH}$ and brix/ acid ratio (Malundo et al., 1997).

The flavour impression is the collective effect of taste recognized by the taste buds and the aromatic compounds detected by the olfactory organs epithelium in the mouth. Flavour score of date bars fortified with different levels of moringa leaf and tamarind seed polyphenolic extracts varied significantly among treatments. Date bars treatment $\mathrm{T}_{1}$ awarded highest flavour score $(7.43 \pm 0.11)$ whereas treatment $\mathrm{T}_{4}$ got the lowest flavour score $(6.33 \pm 0.21)$ by the sensory panelists (Figure 3C).

Texture denotesthose properties of a food product that can be assessedby touch or visually. Texture score of date bars fortified with different levels of moringa leaf and tamarind seed polyphenolic extracts varied significantly among treatments. Date bars treatment $\mathrm{T}_{1}$ were preferred and got maximum texture score $(7.71 \pm 0.14)$ whereas treatment $\mathrm{T}_{6}$ got the minimum texture score $(6.28 \pm 0.22)$ by the sensory panelists (Figure $3 \mathrm{D}$ ).

Organoleptic characteristics are not inter-related generally and contribute independently towards overall sensory quality of foods. Overall acceptability score of fruit bars fortified with different levels of moringa leaf and tamarind seed polyphenolic extracts varied significantly among treatments. Fruit bars treatment $T_{1}$ awarded highest score $(7.63 \pm 0.17)$ followed by treatment $\mathrm{T}_{3}(7.14 \pm 0.14)$ whereas treatment $\mathrm{T}_{4}$ got the lowest overall acceptability score $(6.33 \pm 0.12)$ by the sensory panelists (Figure 3E). Overall, moringa leaf polyphenolic extract fortified date bars especially $2 \%$ fortification level were highly appreciated and preferred by the sensory panelistsand were significantly different from other treatment bars as revealed by LSD-test. Results were in comparison with the earlier investigations of Zeeshan et al. (2017) on date candies quality attributes. 


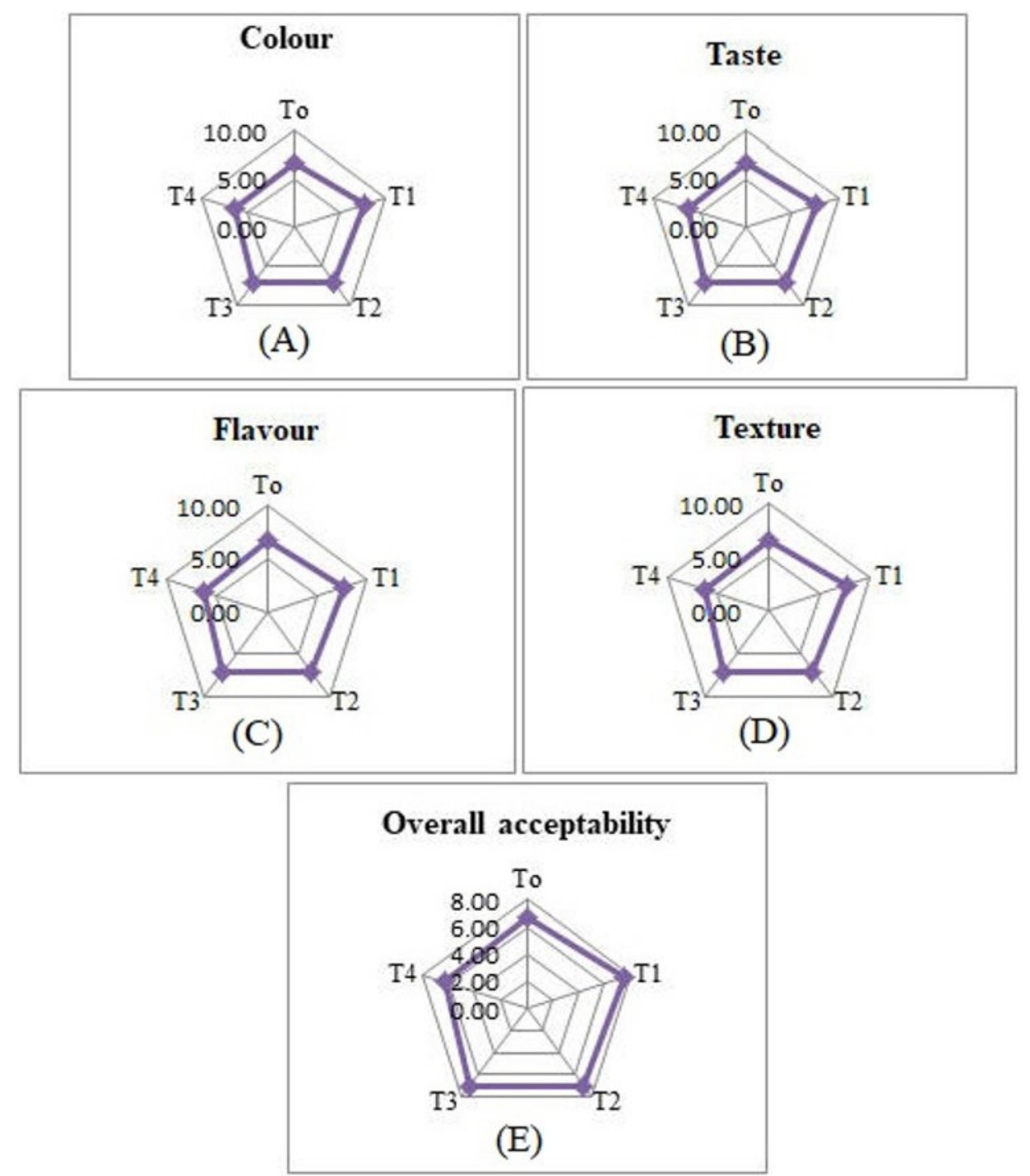

Figure 3. Sensory Evaluation of Date bars. $\mathrm{T}_{0}$ : Control date bars; $\mathrm{T}_{1}: 2 \%$ Moringa leaf extract fortified date bars; $\mathrm{T}_{2}: 3 \%$ Moringa leaf extract fortified date bars; $\mathrm{T}_{3}: 2 \%$ Tamarind seed extract fortified date bars; $\mathrm{T}_{4}: 3 \%$ Tamarind seed extract fortified date bars.

\section{Conclusion}

Higher polyphenols were extracted from moringa leaf with comparatively more antioxidant activity than tamarind seed, mint and lemongrass. Date bars fortified with different levels of moringa leaf and tamarind seedpolyphenolicextracts had optimum quality attributes and antioxidant activityas well assensory acceptable. Overall, $2 \%$ moringa leaf extract fortified date bars scored highest and were appreciated most by sensory panelists whereas $3 \%$ tamarind seed extract fortified date bars scored lowest and were disliked most. It was concluded that moringa leaf and tamarind seed extract being a potential source of polyphenols could be developed as ingredient for the preparation of functionldate bars and other functional food.

\section{Conflict of interest}

The authors declare that they have no competing interests.

\section{Acknowledgements}

The research work was supported by PSDP Project "Productivty Enhancement of Wheat-FSRI Component", Pakistan.

\section{References}

Aadil, R. M., Zeng, X.-A., Wang, M.-S., Liu, Z.-W., Han, Z., Zhang, Z.-H., Hong, J., \& Jabbar, S. (2015). A potential of ultrasound on minerals, micro-organisms, phenolic compounds and colouring pigments of grapefruit juice. International Journal of Food Science \& Technology, 50(5), 1144-1150. http://dx.doi. org/10.1111/ijfs.12767.

Association of Official Agricultural Chemists. (2016). Official Methods of Analysis of AOAC International (20th ed.). Maryland, USA: AOAC.

Bimakr, M., Rahman, R. A., Saleena Taip, F., Adzahan, N. M., \& Islam Sarker, Z. (2013). Ultrasound-assisted extraction of valuable compounds from winter melon (Benincasa hispida) seeds. International Food Research Journal, 20(1), 331-338. 
Brand-Williams, W., Cuvelier, M.-E., \& Berset, C. (1995). Use of a free radical method to evaluate antioxidant activity. LebensmittelWissenschaft + Technologie, 28(1), 25-30. http://dx.doi.org/10.1016/ S0023-6438(95)80008-5.

Daglia, M. (2012). Polyphenols as antimicrobial agents. Current Opinion in Biotechnology, 23(2), 174-181. Doi.org. 10.1016/J. COPBIO. 2011.08.007.

Dewanto, V., Wu, X., Adom, K. K., \& Liu, R. H. (2002). Thermal processing enhances the nutritional value of tomatoes by increasing total antioxidant activity. Journal of Agricultural and Food Chemistry, 50(10), 3010-3014. http://dx.doi.org/10.1021/jf0115589. PMid:11982434.

Farooq, F., Rai, M., Tiwari, A., Khan, A. A., \& Farooq, S. (2012). Medicinal properties of Moringaoleifera: An overview of promising healer. Journal of Medicinal Plants Research, 6(27), 4368-4374.

Gopalakrishnan, L., Doriya, K., \& Kumar, D. S. (2016). Moringa oleifera: a review on nutritive importance and its medicinal application. Food Science and Human Wellness, 5(2), 49-56. http://dx.doi.org/10.1016/j. fshw.2016.04.001.

Jethwani, P., Kochhar, A., \& Javed, M. (2020). Formulation and quality evaluation of antioxidant rich bars enriched with chia seed, whole mango, apple and guava. Current Research in Nutrition and Food Science, 8(3), 975-987. http://dx.doi.org/10.12944/CRNFSJ.8.3.25.

Ma, Z. F., Ahmad, J., Zhang, H., Khan, I., \& Muhammad, S. (2020). Evaluation of phytochemical and medicinal properties of Moringa (Moringaoleifera) as a potential functional food. South African Journal of Botany, 129, 40-46. http://dx.doi.org/10.1016/j.sajb.2018.12.002.

Malundo, T. M., Baldwin, E. A., Moshonas, M. G., Baker, R. A., \& Shewfelt, R. L. (1997). Method for the rapid headspace analysis of mango (Mangifera indica L.) homogenate volatile constituents and factors affecting quantitative results. Journal of Agricultural and Food Chemistry, 45(6), 2187-2194. http://dx.doi.org/10.1021/jf960569c.

Mimica-Dukic, N., \& Bozin, B. (2008). Mentha L. species (Lamiaceae) as promising sources of bioactive secondary metabolites. Current Pharmaceutical Design, 14(29), 3141-3150. http://dx.doi. org/10.2174/138161208786404245. PMid:19075696.

Orrego, C., Salgado, N., \& Botero, C. (2014). Developments and trends in fruit bar production and characterization. Critical Reviews in Food Science and Nutrition, 54(1), 84-97. http://dx.doi.org/10.108 0/10408398.2011.571798. PMid:24188234.

Pérez-Jiménez, J., Serrano, J., Tabernero, M., Arranz, S., Díaz-Rubio, M. E., García-Diz, L., Goñi, I., \& Saura-Calixto, F. (2009). Bioavailability of phenolic antioxidants associated with dietary fiber: plasma antioxident capacity after acute and long-term intake in humans. Plant Foods for Human Nutrition (Dordrecht, Netherlands), 64(2), 102107. http://dx.doi.org/10.1007/s11130-009-0110-7. PMid:19444613.

Pizzino, G., Irrera, N., Cucinotta, M., Pallio, G., Mannino, F., Arcoraci, V., Squadrito, F., Altavila, D., \& Bitto, A. (2017). Oxidative stress: harms and benefits for human health. Oxidative Medicine and Cellular Longevity, 2017, 8416763. http://dx.doi.org/10.1155/2017/8416763.

Ranjha, M. M. A. N., Amjad, S., Ashraf, S., Khawar, L., Safdar, M. N., Jabbar, S., Nadeem, M., Mahmood, S., \& Murtaza, M. A. (2020).
Extraction of polyphenols from apple and pomegranate peels employing different extraction techniques for the development of functional date bars. International Journal of Fruit Science, 20(3), 1201-1221. http://dx.doi.org/10.1080/15538362.2020.1782804.

Razali, N., Junit, S. M., Ariffin, A., Ramli, N. S. F., \& Aziz, A. A. (2015). Polyphenols from the extract and fraction of T. indica seeds protected HepG2 cells against oxidative stress. BMC Complementary and Alternative Medicine, 15(1), 438. http://dx.doi.org/10.1186/s12906015-0963-2. PMid:26683054.

Safdar, M. N., Kausar, T., \& Nadeem, M. (2017). Comparison of ultrasound and maceration techniques for the extraction of polyphenols from mango peel. Journal of Food Processing and Preservation, 41(4), e13028. http://dx.doi.org/10.1111/jfpp.13028.

Singleton, V. L., Orthofer, R., \& Lamuela-Raventós, R. M. (1999). Analysis of total phenols and other oxidation substrates and antioxidants by means of folin-ciocalteu reagent. Methods in Enzymology, 299, 152178. http://dx.doi.org/10.1016/S0076-6879(99)99017-1.

Stone, H., \& Sidal, J. L. (1998). Quantitative descriptive analysis: developments, applications and the future. Food Technology, 52(8), 48-52.

Sultana, B., Anwar, F., \& Ashraf, M. (2009). Effect of extraction solvent/ technique on the antioxidant activity of selected medicinal plant extracts. Molecules, 14(6), 2167-2180. http://dx.doi.org/10.3390/ molecules14062167. PMid:19553890.

Sultana, B., Anwar, F., \& Przybylski, R. (2007). Antioxidant activity of phenolic components present in barks of barks of Azadirachtaindica, Terminaliaarjuna, Acacia nilotica, and Eugenia jambolana Lam. trees. Food Chemistry, 104(3), 1106-1114. http://dx.doi.org/10.1016/j. foodchem.2007.01.019. PMid:26065778.

Tahira, R., Naeemullah, M., Akbar, F., \& Masood, M. S. (2011). Major phenolic acids of local and exotic mint germplasmgrown in Islamabad. Pakistan Journal of Botany, 43, 151-154.

Wang, J., Sun, B., Cao, Y., Tian, Y., \& Li, X. (2008). Optimisation of ultrasound-assisted extraction of phenolic compounds from wheat bran. Food Chemistry, 106(2), 804-810. http://dx.doi.org/10.1016/j. foodchem.2007.06.062.

Williamson, G. (2017). The role of polyphenols in modern nutrition. Nutrition Bulletin, 42(3), 226-235. Doi.org. 10.1111/nbu. 12278.

Wong Paz, J. E., Muñiz Márquez, D. B., Martínez Ávila, G. C., Belmares Cerda, R. E., \& Aguilar, C. N. (2015). Ultrasount-assisted extraction of Polyphenols from native plants in the Mexican desert. Ultrasonics Sonochemistry, 22, 474-481. http://dx.doi.org/10.1016/j. ultsonch.2014.06.001. PMid:25012563.

Wong, Y. S., Sia, C. M., Khoo, H. E., Ang, Y. K., Chang, S. K., \& Yim, H. S. (2014). Influence of extraction conditions on antioxidant properties of passion fruit (Passifloraedulis) peel. Acta Scientiarum Polonorum. Technologia Alimentaria, 13(3), 257-265. http://dx.doi. org/10.17306/J.AFS.2014.3.4. PMid:24887941.

Zeeshan, M., Saleem, S. A., Ayub, M., Shah, M., \& Jan, Z. (2017). Physicochemical andsensory evaluation of Dhakki dates candy. Journal of Food Processing \& Technology, 8(3), 1000663. 